\title{
Indonesian National Development Planning System Based on State Policy \\ Guidelines (GBHN) : A Return to the Future?
}

\author{
Hilaire Tegnan \\ Charles Simabura \\ Saldi Isra \\ Sourbone, Perancis \\ tegnan1@yahoo.fr \\ simabur a@yahoo.com \\ saldiisra@yahoo.com
}

\begin{abstract}
The National Guidelines of State Policy known to the Indonesian people as Garis Besar Haluan Negara (GBHN) used to be a set of political, economic and social principles enacted every five years by the People's Consultative Assembly or Majels Permusyawaratan Rakyat (referred to as MPR hereafter) that had to be followed by both central and regional governments for the prosperity of Indonesia and the Indonesian people. However, since the amendments to the 1945 Constitution (1999-2002), which stripped MPR of much of its power, this national development planning scheme was abolished and decentralization was established throughout Indonesia. Nevertheless, in recent years more voices are being heard demanding the reinstatement of the National Guidelines. This paper discusses the issue of national development planning at the central government level. Drawing on the example of the Indonesian National Guidelines of State Policy, the paper argues that a possible return to the old guideline policy could be counterproductive as it would harm the decentralization process, political freedom, democracy, human rights, and the rule of law in Indonesia.
\end{abstract}

Keywords: Development Planning; Decentralization Process; National Guidelines of State Policy.

\section{A. INTRODUCTION}

The proposal to revive GBHN came from the Indonesian Democratic Party of Struggle (PDI-P) Chairperson Megawati Sukarnoputri in a speech she gave at the launch of the PDI-P National Conference in Jakarta on January 10, 2016. This idea subsequently garnered support from various sides, from academics and the MPR to politicians in the legislature. What would the Indonesian political legal environments look like should this mechanism be restored is the issue this paper endeavors to investigate. As stated at the outset of this paper, the National Guidelines of State Policy was the post-independence guideline of national development plans issued by the People's Consultative Assembly every five years for the head of state and provinces to abide by in carrying out their duties. GBHN was deemed as the common desire of the Indonesian people as a whole 
within the government as the instructions and development policies contained therein were deemed not only to be based on the 1945 Constitution of the Republic of Indonesia, but they should also not contradict it, by no means. ${ }^{1}$ In short, GBHN was considered as a constitution within the 1945 Constitution of the Republic of Indonesia as its initiators strongly believed that it functioned as the vision and mission of the Indonesian nation, thus it was useful in order to determine the direction of national development. Should any Head of state of province deviate from this guideline, they would be accountable for their action before the MPR which was then the highest legislative and governing body within the Indonesia's political system. It is staffed with both members of the People's Representative Council (Dewan Perwakilan Rakyat or DPR) and the members of the Council of Representatives of the Regions (Dewan Perwakilan Daerah or DPD) who have been elected through general elections. This political system is known as Parliament Democracy whereby the Legislative elects the Head of the state instead of a direct election. ${ }^{2}$ The 1945 Constitution of the Republic of Indonesia has undergone four amendments (1999, 2000, 2001, and 2002) and ever since then GBHN is no longer mentioned in the 1945 Constitution of the Republic of Indonesia and MPR has lost much of its power. ${ }^{3}$ However, the idea of returning to the old development planning system--GBHN and repositioning MPR or any other such institution as its depositary, is re-emerging in the Indonesian mainstream media and academics. This paper discusses the prospect of restoring GBHN and the consequences that could flow out of it.

\section{B. DISCUSSION}

\section{Overview of MPR and GBHN}

MPR was formed after the first general election of 1971 . As provided by the 1945 Constitution, the MPR is responsible for: 1) the amendment or removal of certain articles and/or provisions of the Constitution. A one third majority vote in a general session of the Assembly can approve any proposed changes to the constitution including scrapping or adding additional articles, sections and provisions; 2) inaugurate the

\footnotetext{
1 Sofian Effendi, Sistem Pemerintahan Negara Berdasarkan Faham Kekeluargaan dan Idiologi Negara Pancasila. Paper presented at the National Seminar of One Century National Awakening, organized by the Nation Character Building Co-operation Institution in Jakarta, 5 May 2008.

2 Hilaire Tegnan, The Implementation of the Rule of Law in Post Colonial Developing Countries: A case Study of Legal Pluralism in Indonesia. page. 206

3 Sofian Effendi, Sistem Pemerintahan Negara Berdasarkan Faham Kekeluargaan dan Idiologi Negara Pancasila. Paper presented at the National Seminar of One Century National Awakening, organized by the Nation Character Building Co-operation Institution in Jakarta, 5 May 2008.
} 
President and/or Vice President, and 3) dismiss the President and/or Vice-President during his/her term of office if probable violations of the 1945 constitution and the laws of the republic have been committed in carrying out their duties. As per the 2003 Assembly provision, only in a case when both the Presidential and Vice-Presidential positions are vacant can the MPR be advised to hold a general session to elect office holders. Such cases are sudden resignation, impeachment, and death in office. However, since 2002, MPR's has lost much of its power as stated in the outset of this paper. In fact, the 2003 Annual Session of MPR outlined its new status, which came into effect with the inauguration of President Susilo Bambang Yudoyono in 2004. With the President and VicePresident thenceforth elected directly by the people and with the constitutional amendments (1999, 2000, 2001, 2002) ${ }^{4}$ the MPR's power was reduced. It would no longer be the highest governing body but would stand on equal terms with the DPR, BPK, the Supreme Court, and the Constitutional Court. In dealing with the President and VicePresident, the MPR would only be responsible for the inauguration ceremony and, should the occasion call for it, the impeachment of the President or Vice-President, or both. The MPR would elect a President and Vice-President only if both positions were vacant. These basis functions of the MPR are furthered by the Law No. 17/2014 on MPR, DPR, DPD and DPRD which stipulates that, based on the 1945 Constitution, the tasks of the MPR include: 1) publicizing MPR decrees; 2) promoting Pancasila, the 1945 Constitution of the Republic of Indonesia, and the Unity in Diversity; 3) reviewing the constitutional system, the 1945 Constitution of the Republic of Indonesia and its implementation; and 4) absorbing the people's aspirations with regard to the implementation of the Constitution.

\section{Disappearance of GBHN}

After the Assembly endorsed the third and fourth amendment of the 1945 Constitution, the Indonesian system of government turned into a presidential system. Article 1 (2) of the amended Constitution made it clear MPR is no longer the embodiment of the people and the locus of power in the political system. Article 6 A paragraph (1) states that "The President and Vice President are elected as a pair directly by the people". These two articles demonstrate the characteristics of the presidential system, and therefore putting to thirty years of Guided Democracy (Demokrasi Terpimpin). The advent of the Reformation Era (Era Reformasl) has removed GBHN from the 1945 Constitution of

\footnotetext{
${ }^{4}$ Jimly Asshiddiqie, 2004, Konstitusi dan Konstitusionalisme Indonesia. Jakarta, Indonesian Constitutional Court and PSHTN, Faculty of Law , Indonesian Univesity.
} 
the Republic of Indonesia as stated earlier. After the reformation era, MPR is not longer the highest state institutions, but aligns with the three other government branches. MPR thus, no longer issues guidelines for the president to abide by. Under the Reformation Era, the vision and mission of the president and vice president elected as well as laws enacted by the Parliament suffice as national development plans. The reforms brought about by Era Reformasi also include the president and his vice president being accountable directly to the Indonesian people instead of the MPR. In addition, GBHN was removed due the enactment Law No. 22/1999 and Law No. 25/1999, which has been replaced by Law No. 32/2004 and Law No. 33/2004) on regional autonomy. With the passing these laws, there no longer is the need for a central agency to plan development for the whole archipelago of more than two hundred fifty million people to follow. It follows that, from then on, national development is planned by the President and by the laws and regulations while regional development is designed by local authorities in accordance with the law and the 1945 Constitution of the Republic of Indonesia. The extent to which this new political adjustment is beneficial is worth discussing.

\section{Central Planning: A Roadmap to National Development?}

There is no doubt that sustainable national development has to be rationally and thoroughly planned. The problem however, is not who shall be vested with power to make such planning but rather, does planning itself at the central level really lead to real national development? Planning harms democracy, the rule of law and regional autonomy.

\section{Planning and Democracy}

According to Friedrich Hayek (2001) the welfare and the happiness of millions cannot be measured on a single scale of less and more. The welfare of a people, like the happiness of a man, depends on a great many things that can be provided in an infinite variety of combinations. It cannot be adequately expressed as a single end, but only as a hierarchy of ends, a comprehensive scale of values in which every need of every person is given its place. ${ }^{5}$ As Hayek believes that there is no justification for the belief that so long as power is conferred by democratic procedure, it cannot be arbitrary, thus he claims that planning leads to dictatorship because dictatorship is the most effective instrument of coercion and the enforcement of ideals, and as such essential if central planning on a

\footnotetext{
${ }^{5}$ Read Friedrich Hayek (2001), The Road to Serfdom, Routledge Classics. page. 60
} 
large scale is to be possible. ${ }^{6}$ Hayek carries on to say that to imagine that the economic life of a vast area comprising many different people can be directed or planned by democratic procedure betrays a complete lack of awareness of the problems such planning would raise. Planning on a national scale, cannot be anything but a naked rule of force, an imposition by a small group on all the rest of that sort of standard and employment which the planners think suitable for the rest.7 Many of GBHN issues by the Provisional People's Consultative Assembly (Majelis Permusyawatan Rakyat Sementara or MPRS) were inspired by President Soekarno's ideology as the institution itself was subservient to him, with the President deciding everything from the number of seats to the appointment of additional members and the choice of the body's Chairman and Vice Chairmen. The MPRS held its first General Session in Bandung, West Java from 10 November to 7 December 1960. Its main resolution was the adoption of Sukarno's political manifesto as the GBHN and the broad outlines of an eight-year Development Plan, which was set to start in 1961. The second General Session was held in Bandung from 15 May to 22 May 1963. It was at this General Session that Sukarno was elected 'President for Life', a major breach to the Constitution. The MPRS held its third General Session in Bandung from 11 to 15 April 1965. This General Session further entrenched Sukarno's ideological approaches in the running of Indonesia. Many of Sukarno's Independence Day speeches were adopted as the guideline for policies in politics and economics. The MPRS also decided on the principals of Guided Democracy, which would involve consultations (Musyawarah and Mufakat). All these events prove how the MPR, a supposedly independent legislative body was at the mercy of the executive.

\section{Planning and the Rule of Law}

Not only does planning ruin democracy but it is also detrimental to the rule of law. In fact, according to Hayek general rules, genuine laws as distinguished from specific orders, must therefore be intended to operate in circumstances which cannot be foreseen in detail, and, therefore, their effect on particular ends or particular people cannot be known beforehand. It is in this sense alone that it is at all possible for the legislator to be impartial. To be impartial means to have no answer to certain question. He goes on to say that where the precise effects of government policy on particular people are known, where the government aims directly at such particular effects, it cannot help knowing these

\footnotetext{
6 Ibid. page. 74

7 Ibid. page 229
} 
effects, and therefore it cannot be impartial. It must, of necessity, take sides, impose its valuations upon people, and, instead of assisting them in the advancement of their own ends, choose the ends for them. As soon as the particular effects are foreseen at the time a law is made, it ceases to be a mere instrument to be used by the people and becomes instead an instrument used by the law-giver upon the people and for his ends. ${ }^{8}$ Hayek asserts that planning for the people leaves them with no possibility of making their own choice for matters directly affecting their every life. The more the state "plans" the more difficult planning becomes for the individual. ${ }^{9} \mathrm{He}$ argues that:

If all rewards, instead of being offered in money, were offered in the form of public distinctions or privileges, positions of power over other men, or better housing or better food, opportunities for travel or education, this would merely mean that the recipient would no longer be allowed to choose, and that, whoever fixed the reward, determined not only its size but also the particular form in which it should be enjoyed. ${ }^{10}$

\section{Planning and Regional Autonomy}

Nowhere has democracy ever worked well without a great measure of local selfgovernment, as Hayek astutely puts it. ${ }^{11}$ To split or decentralize power is necessarily to reduce the absolute amount of power and the competitive system is the only system designed to minimize by decentralization the power exercised by man over man. ${ }^{12} \mathrm{~A}$ return to a central planning of national development as the case of GBHN could impair the ongoing decentralization process that provinces have fought so hard to achieve. A central planning would mean local governments would have little if not no say in their local affairs, which could increase the prospect of riots and secessions. ${ }^{13}$ Needless to say that if it was not for decentralization, the Free Aceh Movement or Gerakan Aceh Merdeka (GAM), Kalimantan, Sulawesi, and the Free Irian Jaya (now Papua) Movement or Organisasi Papua Merdeka (OPM) might not have given up their secession plans. The case of Aceh is of an importance because of the role decentralization played in pacifying the region. In

\footnotetext{
${ }^{8}$ Ibid. page. 80

${ }^{9}$ Ibid. page 79

${ }^{10}$ Ibid. page. 93

${ }^{11}$ Ibid. page. 241

12 Ibid. page. 149

${ }^{13}$ See Keith Green, Decentralization and good governance:The case of Indonesia. MPRA Paper No. 18097, on 26 October 2009
} 
fact, in August 2005 the Susilo Administration and GAM's leaders reached an accord during negotiations in Finland. The insurgents agreed to surrender their weapons and to drop their demand for independence. In return, the government offered limited selfgovernment, free and direct elections for provincial leaders, and local control over much of Aceh's oil and natural gas resources. ${ }^{14}$ Furthermore, a return of the GBHN would be unconstitutional as the Article 18 Section 2 of the amended 1945 Constitution of the Republic of Indonesia stipulates that local authorities of the provinces, regencies, and municipalities shall administer and manage their own affairs according to the principles of regional autonomy and the duty of assistance (tugas pembantuan). Its Section 3 sets forth that the authorities of the provinces, regencies, and municipalities shall include for each a DPRD whose members shall be elected through general elections. Section 4 on the other hand is more concerned with democracy and the administrative authority partition of Indonesia when it instructs that Governors, Regents (bupati) and Mayors (walikota), respectively as head of regional government of the provinces, regencies and municipalities, shall be elected democratically. Section 5 prescribes that the regional authorities shall exercise wide-ranging autonomy, except in matters specified by law to be the affairs of the central government. Finally, Section 6 confer authority to provinces to enact their own regulations when it prescribes that regional authorities shall have the authority to adopt regional regulations and other regulations to implement autonomy and the duty of assistance. To enforce these constitutional provisions, Law No. 22 and 25 on Regional autonomy was drafted in 1999, but it was not until 2001 that it was implemented. This law was then repealed by Regional Governance Law No 32 of 2004.

\section{GBHN and Political Freedom}

Nearly every democratic country agrees with the fact that government should be watched and be held accountable for its actions by the people, hence the allocation of power to certain institutions to perform such task. But, the fact that precaution is taken to prevent government from being too much powerful does not mean the actions a head of state are or should be confined within some ready made guidelines which he or she has not power whatsoever to alter so as to meet the needs of a situation unforeseen by those who issued the guidelines. As argued earlier, sustainable development requires a thorough

${ }^{14}$ See Arskal Salim, Dynamic Legal Pluralism in Indonesia: the shift in plural legal orders of contemporary Aceh A Paper presented at the First International Conference on Aceh and Indian Ocean Studies, Banda Aceh 24-26 February 2007. 
and rational planning. But laying down inflexible guidelines for the head of state to follow throughout his or her time in office might seem just irrational as human activities and behaviors evolve over the years. The fact that a head of state is granted discretionary powers by their constitution justifies this. Human activities, including economic and political activities, get fluctuant as time goes by, which makes it difficult to make predictions by setting up. Therefore, ready-made rules to boost development may lead to the very opposite of the intended goals. Moreover, laying down rules or guidelines for a new head of state along with their government to stick to not only leaves them with no power to make important decisions but it also subordinates them to the institution/body that issues those rules or guidelines. Under such political arrangement, a head of state is nothing more than a puppet. Besides, is the head of state not supposed to be smart and creative? "He will be able to obtain the support of all the docile and gullible, who have no strong convictions of their own but are prepared to accept a ready-made system of values if it is only drummed into their ears sufficiently loudly and frequently". ${ }^{15}$ One should not forget that it takes lots of money to get someone elected as head of state with regard to the huge sum of money spent during campaigns. It would make little sense to get into office after spending a fortune and have some institution tell you how to run the country (exception should be made here for international monetary institutions). If such institution existed, it would be quickly taken over by whoever runs the country. Such was the case for the MPR under both Soekarno and Suharto. During the New Order, the MPR, mainly staffed by military officers and Golkar party members, ${ }^{16}$ routinely returned Suharto to the presidency, unopposed. ${ }^{17}$ The New Order ended when President Suharto was forced to step down after he was given a seventh term by the MPR.

\section{CONCLUSION}

In conclusion, it is noteworthy that laws and policies need to be synchronized for the sake of consistency, which is needed for a sustainable development of the state as a whole. Another element needed for such a development is serious planning as this helps grasp all the circumstances and aspects of the issue being dealt with. But planning development at the central government level for the whole country is counterproductive. The reformation of the national development planning system needs to take into account

\footnotetext{
${ }^{15}$ Read Friedrich Hayek (2001), The Road to Serfdom, Routledge Classics. page 142

${ }^{16}$ See Herbert Feith, Suharto's Search For a Political Format, Australia's Neighbours, May-June 1968

17 Read Ikrar Nusa Bhakti et al., Military Politics, Ethnicity, and Conflict in Indonesia. Crise Working Paper No. 62 January 2009. page 6
} 
the fact that great achievements in human history have always been the fruits of individual efforts, not the result of some government planning. History provides countless such cases in all fields of study. The gradual transformation of a rigidly organized hierarchic system into one where men could at least attempt to shape their own life, where man gained the opportunity of knowing and choosing between different forms of life, is closely associated with the growth of commerce. ${ }^{18}$ The return of the GBHN model with regard to national development planning system would cause a threat to democracy and the rule of law in Indonesia. The basis of democracy is the opportunity the people have to make choices and decisions for themselves. And this creates autonomy which the rule of law is all about. MPR can be very just and contribute enormously to economic prosperity if it merely keeps order and creates conditions in which the people can develop their own life. Laws work best when they are made by the people they directly affect. Contradictions between laws and policies may arise, but that is the trues manifestation of democracy. "It is probably true that in general the higher the education and intelligence of individuals becomes, the more their views and tastes are differentiated and the less likely they are to agree on a particular hierarchy of values. It is a corollary of this that if we wish to find a high degree of uniformity and similarity of outlook, we have to descend to the regions of lower moral and intellectual standards where the more primitive and "common" instincts and tastes prevail. This does not mean that the majority of people have low moral standards; it merely means that the largest group of people whose values are very similar are the people with low standards". 19

\section{BIBLIOGRAPHY}

Arskal Salim. Dynamic Legal Pluralism in Indonesia: the shift in plural legal orders of contemporary Aceh A Paper presented at the First International Conference on Aceh and Indian Ocean Studies, Banda Aceh 24-26 February 2007

Effendi Sofian. Sistem Pemerintahan Negara Berdasarkan Faham Kekeluargaan dan Idiologi Negara Pancasila Paper presented at the National Seminar of One Century National Awakening, organized by the Nation Character Building Co-operation Institution in Jakarta, on 5 May 2008.

Friedrich Hayek. 2001. The Road to Serfdom, Routledge Classics.

\footnotetext{
${ }^{18}$ Read Friedrich Hayek (2001), The Road to Serfdom. page 142-143

${ }^{19}$ See Friedrich Hayek (2001), The Road to Serfdom. page. 142
} 
Herbert Feith. 1968 Suharto's Search For a Political Format, Australia's Neighbours, MayJune Green, Keith: Decentralization and good governance:The case of Indonesia. MPRA Paper No. 18097, 26. October 2009.

Hilaire Tegnan. The Implementation of the Rule of Law in Post Colonial Developing Countries: A case Study of Legal Pluralism in Indonesia. Ph.D. Dissertation defended on January 30, 2016 Andalas University

Ikrar Nusa Bhakti et al., Military Politics, Ethnicity, and Conflict in Indonesia. Crise Working Paper No. 62 January 2009.

Jimly As-shiddiqie. 2004. Constitution and Indonesian Constitutionalism. Jakarta, Indonesian Constitutional Court and PSHTN. Fakultas Hukum. Univesitas Indonesia. 